\title{
Life cycle characteristics in Tanytarsus sylvaticus (van der Wulp, 1859) (Chironomidae, Diptera)
}

\author{
B.R. Goddeeris 1
}

Keywords : Chironomidae, life cycle, diapause, imaginal discs.

The life cycle of Tanytarsus sy/vaticus (van der Wulp, 1859) has been analysed in two quite different sites in Belgium (Mirwart, Ardennes and Diksmuide, West-Flanders). T. sylvaticus is strictly univoltine; its single emergence period occurs in early spring. A summer diapause in the $3 r d$ instar is typical of this species. The synchronization of the emergence period, however, seems to depend, on a second diapause, this time in the 4th instar, during winter.

Caractéristiques du cycle de vie chez Tanytarsus sylvaticus (van der Wulp) (Chironomidae, Diptera)

Mots clés : Chironomidae, cycle de vie, diapause, disques imaginaux.

Le cycle de vie de Tanytarsus sylvaticus (van der Wulp, 1859) a été analysé dans deux régions fort différentes de la Belgique (Mirwart, Ardennes et Diksmuide, Flandre Occidentale). T. sylvaticus est strictement univoltine et la seule période de vol se situe au dèbut du printemps. Une diapause d'été dans le 3ème stade larvaire est typique pour cette espèce. La synchronisation de la période de vol semble dépendre d'une seconde diapause, cette fois dans le 4ème stade et en hiver.

\section{Introduction}

Many chironomid species have more or less distinct emergence periods (Mundie 1957, Reiss 1968, Laville 1971). The season (s) in which such periods occur are species dependent. These observations are supported mainly by investigations on adults by means of emergence traps. Analyses of the life cycle by monitoring the larval populations, however, are far less common, and this is especially true for multivoltine species. One could nevertheless expect that such emergence periods are also reflected in the larval populations. Furthermore, larval stages are in fact the growth phase in the life history of a species and adult chironomids do not take up energy from the environment. Therefore, an analysis of the life cycle of a species by monitoring the larval population is a recommendable way to tackle life history studies.

1. B.R. Goddeeris, Koninklijk Bejgisch Instituut voor Natuurwetenschappen, Zoetwaterbiologie, Vautierstraat 29, B-1040 Brussel, Belgium.
In order to reveal the main characteristics of the life cycle of a number of chironomid species, two trout-ponds at Mirwart (Belgian Ardennes) were studied over a two-year period (May 1976-May 1978) (Goddeeris 1983). From these investigations, it could be concluded that diapause phenomena are important in life cycle strategies in chironomids. This was especially true for the genus Tanytarsus (Goddeer is 1986, 1987).

It appeared from the Mirwart data that Tanytarsus sylvaticus has a highly specialized life cycle, i.e. it is characterized by a summer diapause in the $3 \mathrm{rd}$ instar stage. Unfortunately, the Mirwart data of autumn and winter were insufficient and so the winter activity in this species could not be elucidated. Therefore, and also to confirm the life cycle pattern observed at Mirwart, a larval population of $T$. sylvaticus from a different region was monitored, this time in the Blankaart reservoir at Diksmuide (West-Flanders, Belgium), from February 1985 to April 1986.

This paper is a synthesis of our investigations on T. sylvaticus at Mirwart and Diksmuide. It is the first of a series of life cycle analyses in Tanytarsusspecies. 


\section{Material and Methods}

\subsection{The trout-ponds at Mirwart}

For an extensive description of this locality, see Marlier \& Wattiez (1977). The ponds are situated in the Belgian Ardennes at an altitude of about $300 \mathrm{~m}$. a.s.l. ; approximate coordinates : $50^{\circ} 2^{\prime} \mathrm{N}$, $5^{\circ} 14^{\prime} \mathrm{E}$. They originated from a series of dams in the valley of the Marsau (fig. 1). These waters have been used as nurse-ponds for trout (Salmo trutta fario). They receive their waters from the Marsau brook, which is poor in nutrients. In order to increase the fish production, some of the ponds are fertilized. Pond IV, however, was left in its original state, in an attempt to reveal the effect of fertilization on fish production. Therefore, the inlet system of the ponds separates pond IV from the others. As a result, pond III is rather eutrophic and pond IV oligotrophic. Chironomids were studied in ponds III and IV only. Pond III is rectangular (3567 $\mathrm{m}^{2}$ ) and has an average depth of $1.5 \mathrm{~m}$ (max. $2.1 \mathrm{~m})$. Pond IV is subtriangular $\left(3152 \mathrm{~m}^{2}\right)$ and has an average depth of $1.2 \mathrm{~m}(\max .1 .7 \mathrm{~m})$. The mudlayer, with a mineral fraction consisting predominantly of silt, covers $90 \%$ of the bottom in pond III and $83 \%$ in pond IV ; the remainder consists of stones and boulders.

Water blooms were observed only in pond III, where half of the bottom surface was covered with Aphanothece stagnina. Macrophyte growth in the ponds was restricted, both around the margins and in the open water in the period 1986-77. In pond IV there was only a dense bed of Glyceria near the inlet, and a few Ramunculus flammula-stands in the open water.

Each year, around mid-October, the ponds were drained. They remained empty until mid-December. However, there were still puddles left and the

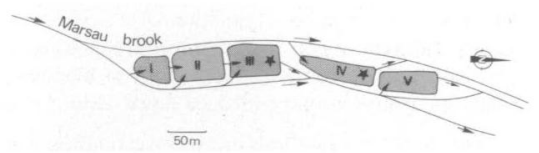

Fig. 1. Map of the trout-ponds at Mirwart (Ardennes) : pond III and IV indicated by an asterisk. sediment remained wet as water filtered in from the Marsau. This drainage did not seem to influence growth of the chironomid larvae but rather, as can be expected, their mortality.

Each pond was well mixed. Dissolved oxygen concentration close to the bottom fluctuated around saturation in both ponds. Water temperature was measured two to four times each month ; measurements at $30 \mathrm{~cm}$ depth are given in $f i g ~ 2 \mathrm{~A}-\mathrm{B}$.

\subsection{The Blankaart reservoir at Diksmuide}

The Blankaart reservoir at Woumen-Diksmuide is situated in the polders of West-Flanders near the river Yser $\left( \pm 3.5 \mathrm{~m}\right.$ a.s.l. ; $50^{\circ} 59^{\prime} 15^{\prime \prime} \mathrm{N}, 2^{\circ} 50^{\prime}$ E). It is an entirely artificial reservoir and serves as a supply of drinking water. It has a regular octogonal shape ( $60 \mathrm{ha}$ ) lined by vertical concrete walls (fig. 3). The reservoir is half crossed by a central wall for water circulation purposes. The whole reservoir is situated above the ground level.

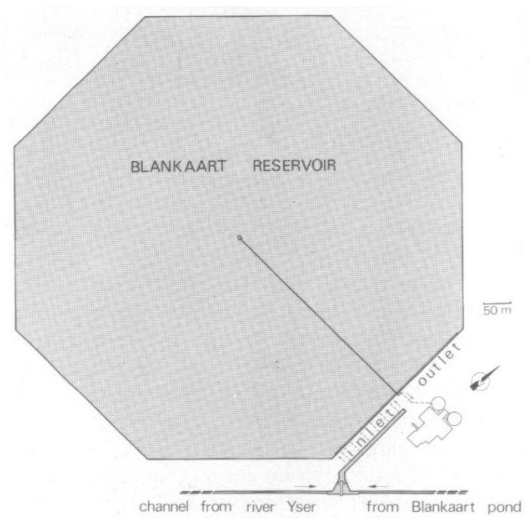

Fig. 3. Map of the Blankaart reservoir at Diksmuide (WestFlanders).

The Blankaart reservoir is in constant use and therefore has a strongly fluctuating water level. The maximum depth of $5 \mathrm{~m}$ is reached in spring, depending on the quality of the inlet water during the input period. A minimum of about $1 \mathrm{~m}$ is left by winter. 

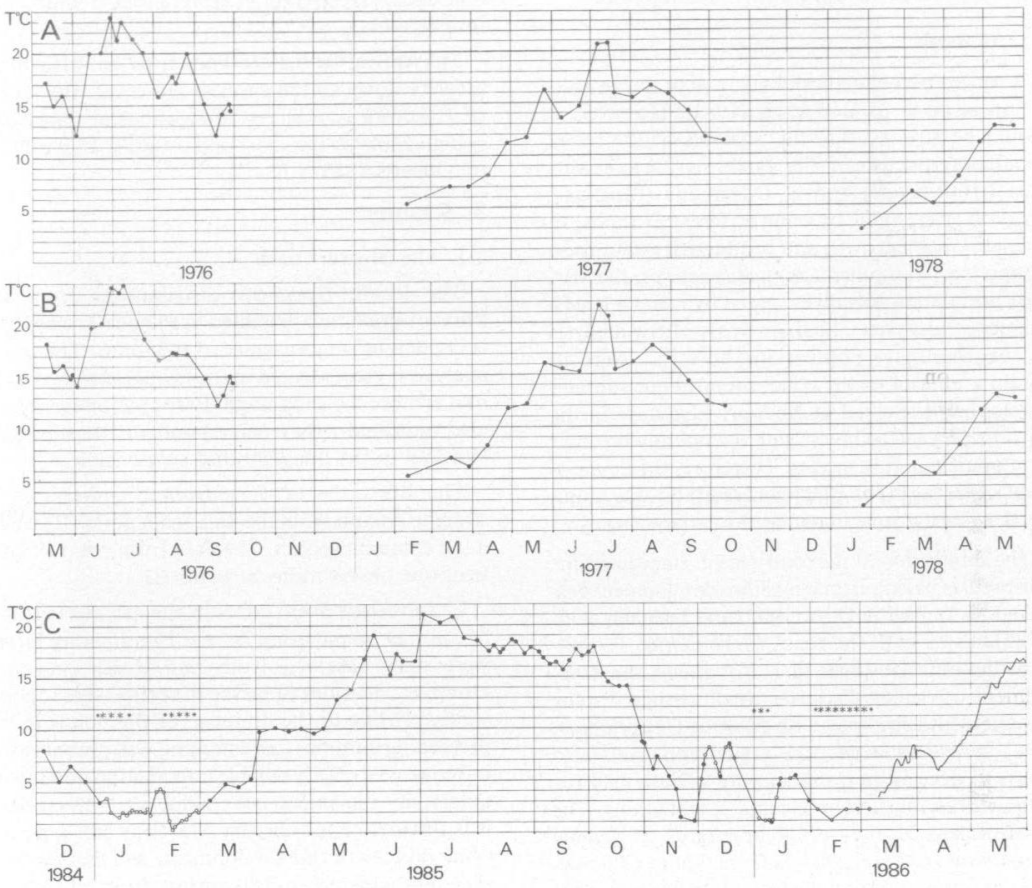

Fig. 2. Surface water temperatures in Mirwart pond III (A) and IV (B) ; bottom water temperatures in the Blankaart reservoir (C) in situ (full dots), from outlet water (open dots) and continuous measurement (full line), asterisks in $C=$ ice cover.

The bottom of the reservoir is also mainly artificial. The floor consists of welded polyethylene sheets, covered by a sand-layer of $20 \mathrm{~cm}$. Since the reservoir became operational in 1973, a fine sediment from the inlet water has settled down upon the sand. In 1986, this mud-layer did not exceed $5 \mathrm{~cm}$ over more than half the surface of the reservoir ; maxima of $20-25 \mathrm{~cm}$ were measured in some places in the south-western part of the reservoir. There were no macrophytes. The simple and rather uniform characteristics of the bottom, combined with a rich chironomid fauna, were decisive in the choice of the Blankaart reservoir for this study on larval population dynamics.

The Blankaart reservoir is a euthrophic water (Van Damme et al. 1987). Algal blooms of Cyclotella and Stephanodiscus were observed during 1985-86. Oxygen concentration usually fluctuated between $80-120 \%$ saturation, and rarely were bottom waters depleted (a single minimum of $58 \%$ was measured on 18th March 1986). The figure 2.C 
illustrates fluctuations in water temperature in the Blankaart reservoir during this investigation.

\subsection{Methods}

A survey of the methodology used in this investigation is given in Goddeeris (1989). However, it should be stressed that the analyses of the larval population structure of Tanytarsus sylvaticus at Mirwart (trout-ponds) and at Diksmuide (Blankaart reservoir) were made by using different methods. In order to obtain growth and productivity data for a comparison with other Tanytarsus-species, the Mirwart population was investigated by using a length frequency analysis. The main goals of the analysis of the Blankaart population, however, were to obtain a control of the conclusions about summer development reached at Mirwart (diapause in the third instar) and to investigate the unknown winter development in this species. Therefore, the development of larvae in the Blankaart reservoir was monitored by instar and imaginal dise analysis only.

The subdivision of the fourth instar stage into nine substages is based on imaginal disc development described by Wülker \& Götz (1968) and Ineichen et al. (1983) in species of the genus Chironomus. To establish the nine substages in $T$. sylvaticus, the development of the leg discs was used, as they display a convenient homology with those of Chironomus. In $T$. sylvaticus males, the sexual apparatus also seems to develop in a similar way as described for Chironomus thummi by Wülker \& Götz (l.c.). The development of the sexual apparatus of female Tanytarsus, however, differs from that in Chironomus, and is therefore difficult to homologize. Also quite different is the development of the thoracic horn, although this feature remains useful for identification once the substages are established for a given species.

The figure 4 illustrates the development of the thoracic discs in $T$. sylvaticus and the subdivision of the 4th instar stage into nine substages (IV1 to IV9). Furthermore, it was possible and even useful to distinguish an early and a late phase in each substage e.g. IV7a and IV7b respectively.

As was already mentioned in the literature (Ineichen et al., 1983), the determination of the substages in imaginal disc development of individual larvae is not straightforward. The main possible error factors are : (1) deformation due to fixation, (2) phase differences in the development of the different discs, (3) different interpretations of individual investigat ors.

Tanytarsini-larvae are known to be difficult to identify down to the species. However, the larvae of $T$. sylvaticus, even the youngest instars, are easily recognizable by the short and rounded anal tubules (Goddeeris 1985).

\section{Results}

\subsection{The Mirwart data}

The length frequency distributions from the Mirwart-ponds are presented in Plate I. The abscissa is divided in length classes of $0.25 \mathrm{~mm}$. The instar analysis is incorporated in the histograms by the use of a symbol for each stage. Prepupating larvae are also indicated ; they correspond to the substages IV8-IV9 in the imaginal disc subdivision.

The life cycle of $T$. sylvaticus appears most straightforward from the data from pond III, where it is a common species. The data from pond IV confirm our observations in pond III.

$T$. sylvaticus overwinters in the 4 th instar stage, but not as prepupating larvae. Prepupating larvae were only observed from mid-March onwards. However, densities of larvae in spring were too low (probably due to the drainage of the ponds in the preceeding autumn) and sampling was probably too infrequent to obtain reliable information about winter activity and emergence conditions. Nevertheless, it is obvious that February-March is still a period of larval growth and development, and that the winter cohort emerges in early spring, from mid-March to mid-April.

First instars of a new cohort also appear in April. In all probability, they are the descendants of the first cohort emerged just before and constitute therefore a new generation. Growth and development of the larvae of this second cohort seem to be regular and continuous in the beginning : development up to the 3rd instar stage required less than one and a half months. In the 3rd instar stage, growth and development come to an arrest : not a single larva moulted to the 4th instar stage during the whole of summer, although fullgrown 3rd instars were present all the time. Only from mid-September onwards are the first 4th instars observed. It should be noted, however, that the majority of the 3rd instars have a length of $3-3.5 \mathrm{~mm}$ in summer and are 

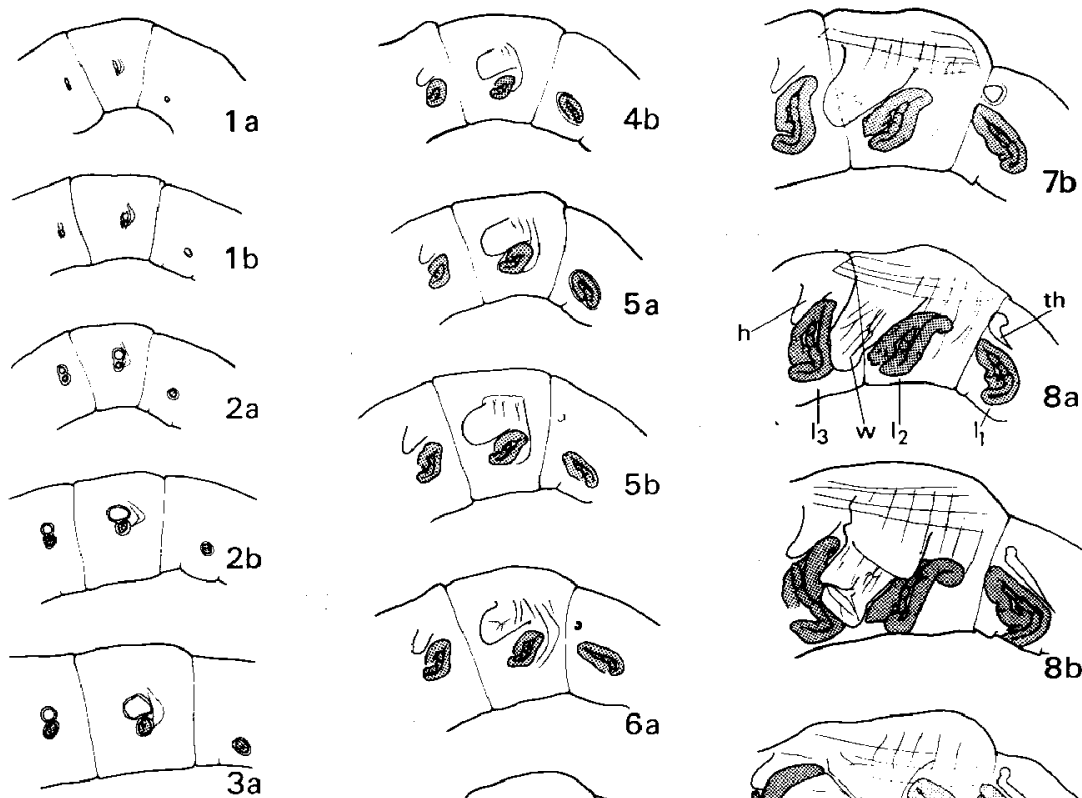
b
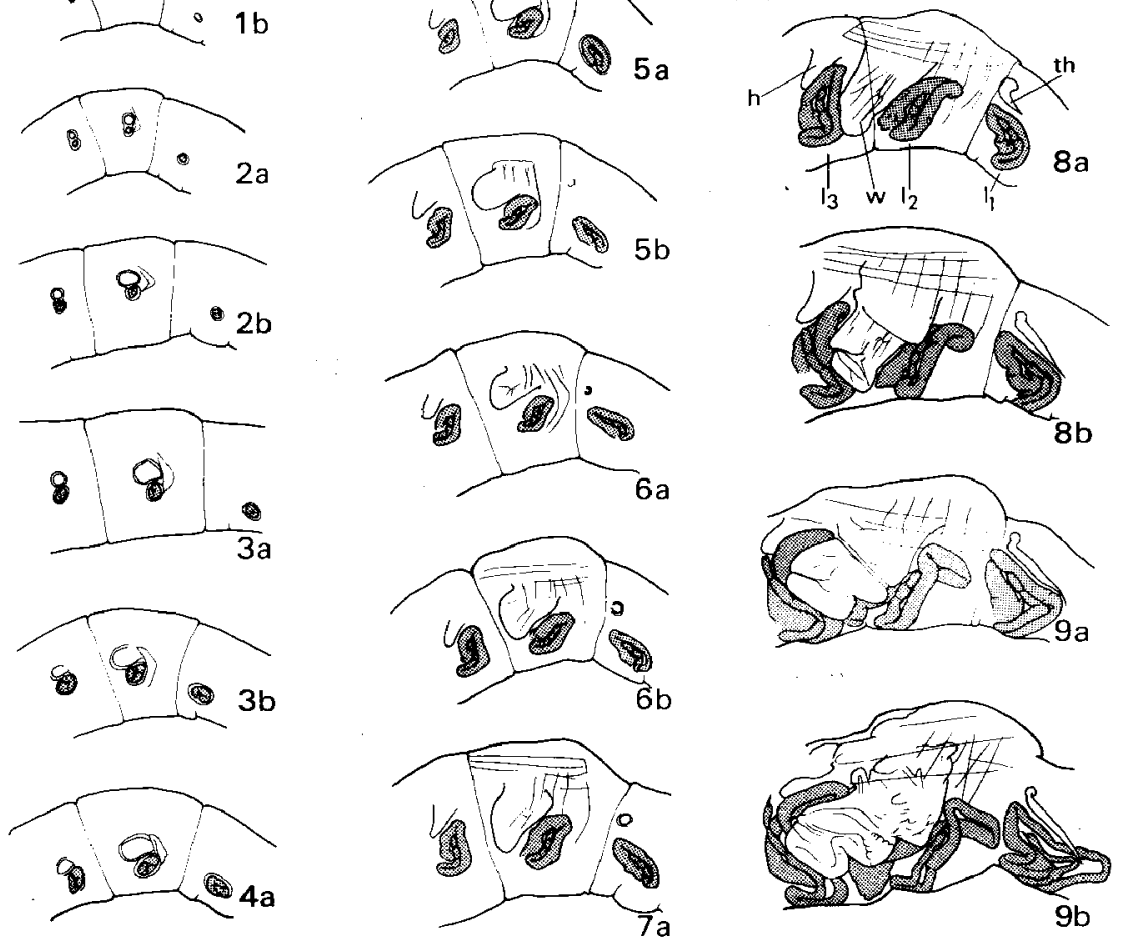

Fig. 4. Tanytarsus sy/vaticus : thorax in right lateral view showing imaginal discs in the IVth instar stage : subdivision in the nine substages, each with an early (a) and late (b) phase ; $h=$ halter, $1_{1}=$ foreleg, $1_{2}=$ middle leg, $1_{3}=$ hind leg, th $=$ thoracic horn, $w=$ wing. 

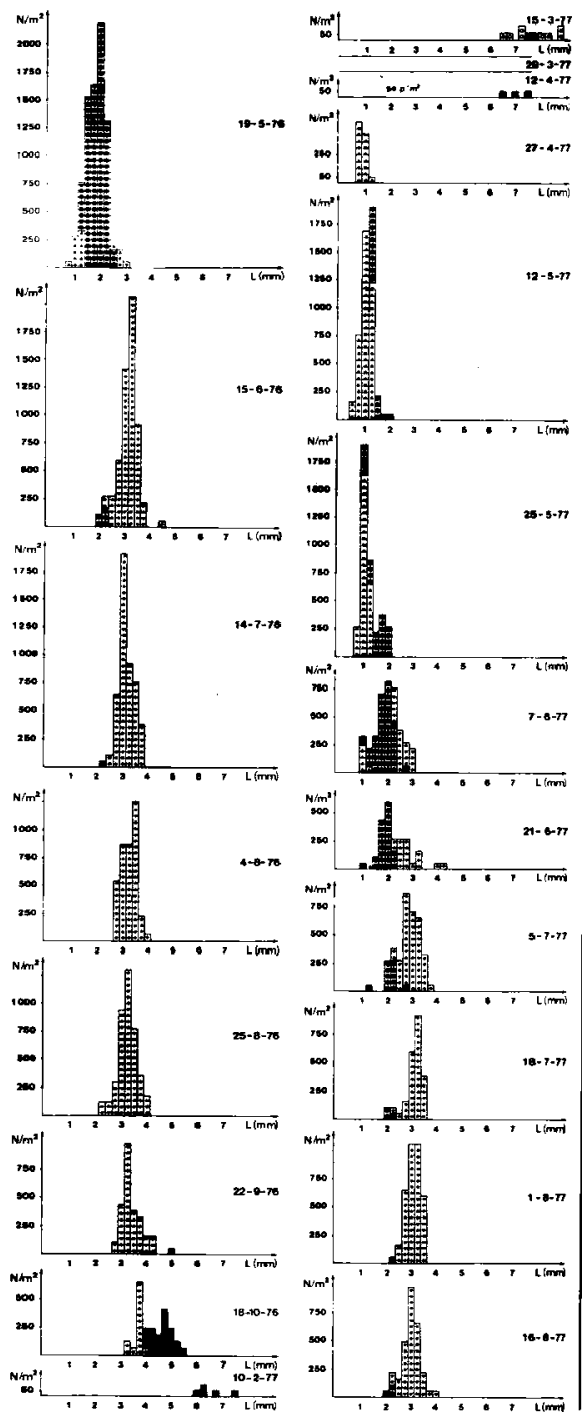

\section{PLATE I}
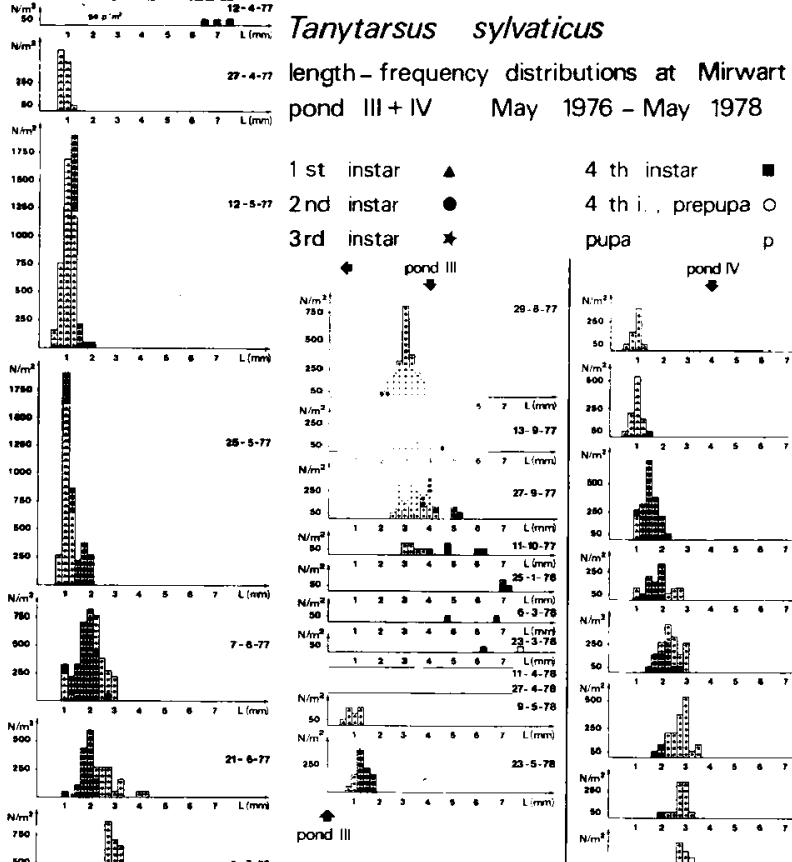

4 th instar

4 th i., prepupa 0

pupa $p$
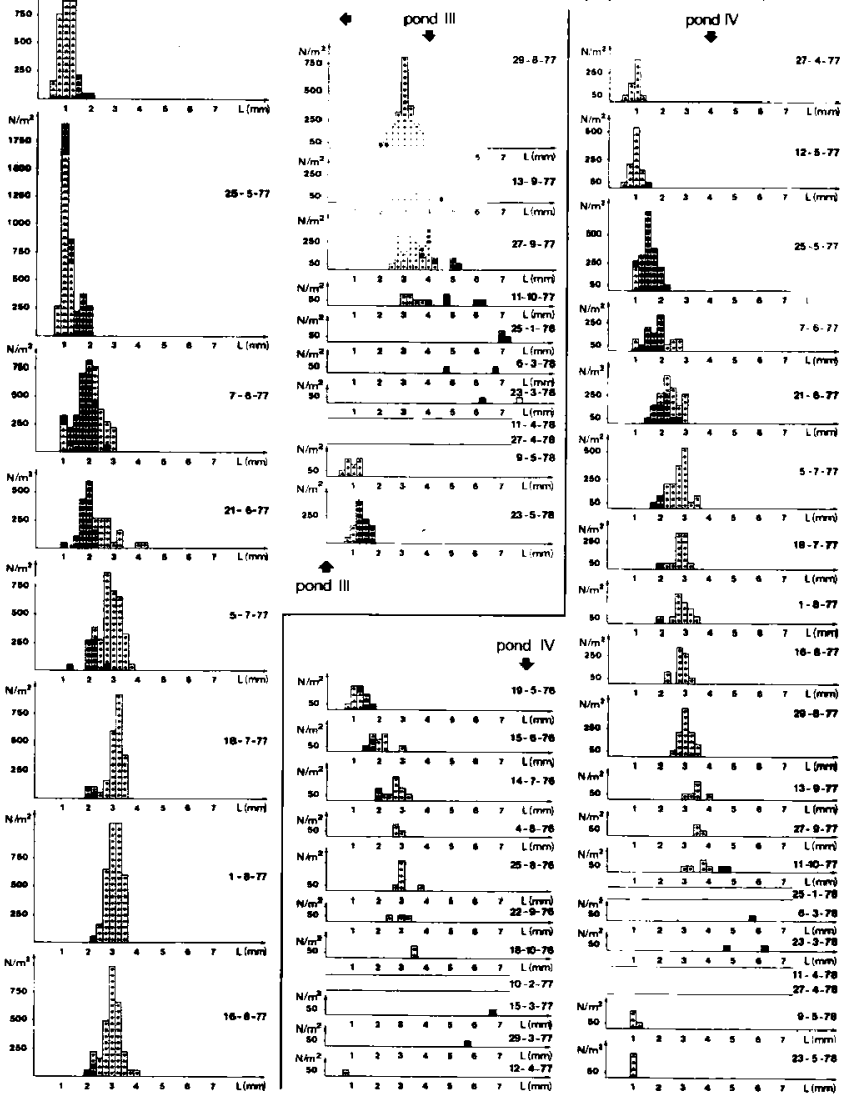
therefore not fullgrown. The length of moulting 3rd instars is notably superior, i.e. about $4 \mathrm{~mm}$.

From mid-September onwards, a new period of growth and development starts. In mid-October, about half of the population has already moulted to the 4 th instar stage. Despite the drainage of the pond in the second half of October, the remainder of the $3 \mathrm{rd}$ instars are observed the following year. This cohort overwinters and will emerge in spring as the single generation of $T$. sylvaticus.

\subsection{The Blankaart data}

The frequency distributions of the larval stages from the Blankaart reservoir are presented in Plate II. The larval instar stages I-IV are indicated in the abscissa, with a subdivision for the nine imaginal disc substages and their early and late phases. The instar stages I-III are represented by the same symbols as used for the Mirwart data in Plate I. The imaginal disc development is rendered more readable in the histograms by the use of a progressive shadowing in the presentation of the substages. The proportion male/female larvae is indicated in the circles below, from substage IV3 onwards : black for males, white for females.

In late winter (12.2.85) the entire population forms a narrow cohort in the 4 th instar stage : only larvae between the substages IV5a - IV8a are observed. Three weeks later (7.3.85), this cohort has become even narrower, the IV 5a-b larvae being scarcely present. It is also obvious that the histogram has become skewed to the left by a displacement of the mode from substage IV $6 \mathrm{~b}$ to IV7b and by the absence of IV $8 \mathrm{~b}$-larvac.

One fortnight later (25.3.85) the structure of the overwintering cohort has changed completely : nearly all larvae are prepupating and some of them are already in the pupal stage. The whole cohort emerges within three weeks and has completely disappeared from the sediment by mid-April.

As in Mirwart, the 1st instars of a new cohort start to appear towards the end of April. This period of natality lasts less than six weeks. The natality peak is situated in the first half of May and by 20th May, 1985 , the majority of the larvae have already moulted to the 2nd instar stage.

Should development be continuous, then one could expect 4 th instars at least from mid-June onwards. However, only in mid-Septembre (9.9.85) are the first 4th instars observed. During summer, the whole of the population is settled in the $3 \mathrm{rd}$ instar stage; the few 2 nd instars still present in the beginning of July (1.7.85) have moulted to the 3 rd instar stage only by August.

Mouting to the 4th instar stage never occurs before autumn. During winter, the cohort becomes progressively narrower. On 27 th January, 1986, only substages IV6b to IV8a are observed and their distribution is fairly skewed to the left.

Due to ice coverage, no sampling was done in February-early March 1986. However, by mid-March, the whole population had moved into the prepupating substages IV8-IV9 or even into the pupal stage. The first adult males of $T$. sylvaticus were observed around the Blankaart reservoir on 17th March, 1986 (see below). One fortnight later $(1.4 .86)$, nearly the entire population had emerged.

Males in chironomids frequently emerge somewhat earlier than females (Oliver 1971), but there is always an important overlap of the emergence periods. The differences in development of the larvae of both sexes have not been analysed in detail in the Blankaart. However, there is a clear tendency in the male larvae to be somewhat further developed than the female before the onset of the actual emergence period (cf. 7.3.85 and 27.1.86). The few larvae and pupae observed at the end of the emergence period are always female (cf. 9.4.85 and 1.4.86).

The emergence of $T$. sylvaticus in spring 1986 is confirmed by collecting adult males with a Malaise trap near the reservoir (fig. 5). The first adults were

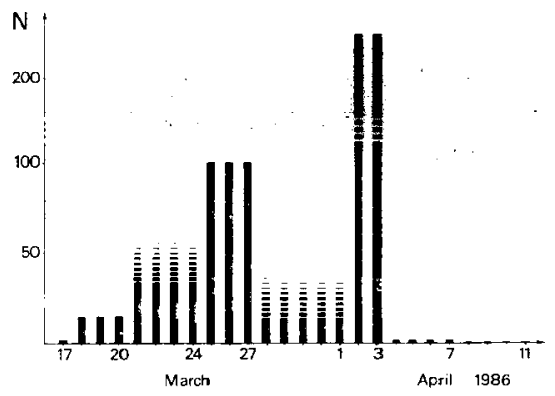

Fig. 5. Tanytarsus sylvaticus captures with a Malaise trap at the edge of the Blankaart reservoir in $1986 ; \mathrm{N}=$ absolute numbers of males divided over the time between the sampling dates ; samples were partially lost by storm between $21.3-24.3$ and 29.3 $-1.4 .1986$. 


\section{Tanytarsus sy/vaticus}

frequency distributions of the larval stages in the Btankaart reservoir February 1985 - April 1986

$\begin{array}{llll}1 & \text { st instar I } & \text { A } & 2 \text { nd in } \\ 3 \mathrm{rd} \text { instar Ill } & \text { pupa } \mathrm{p}\end{array}$

4 th instar substages $1.9\{a+b\}$

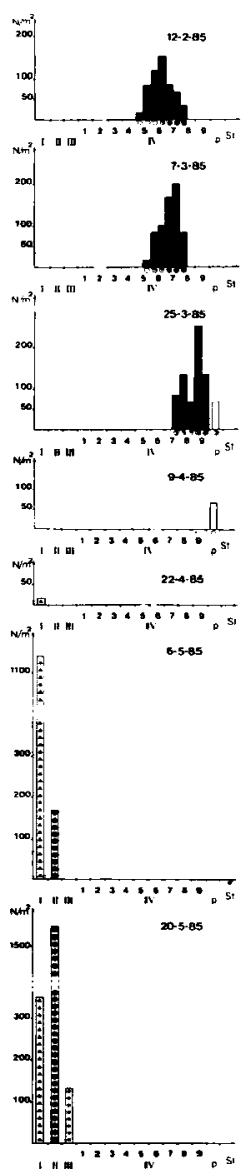

PLATE II
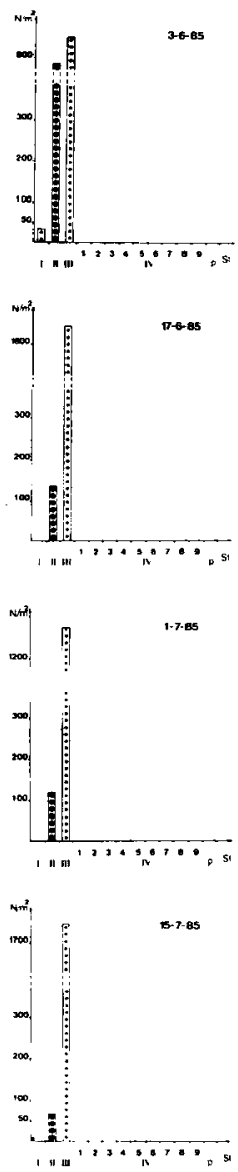
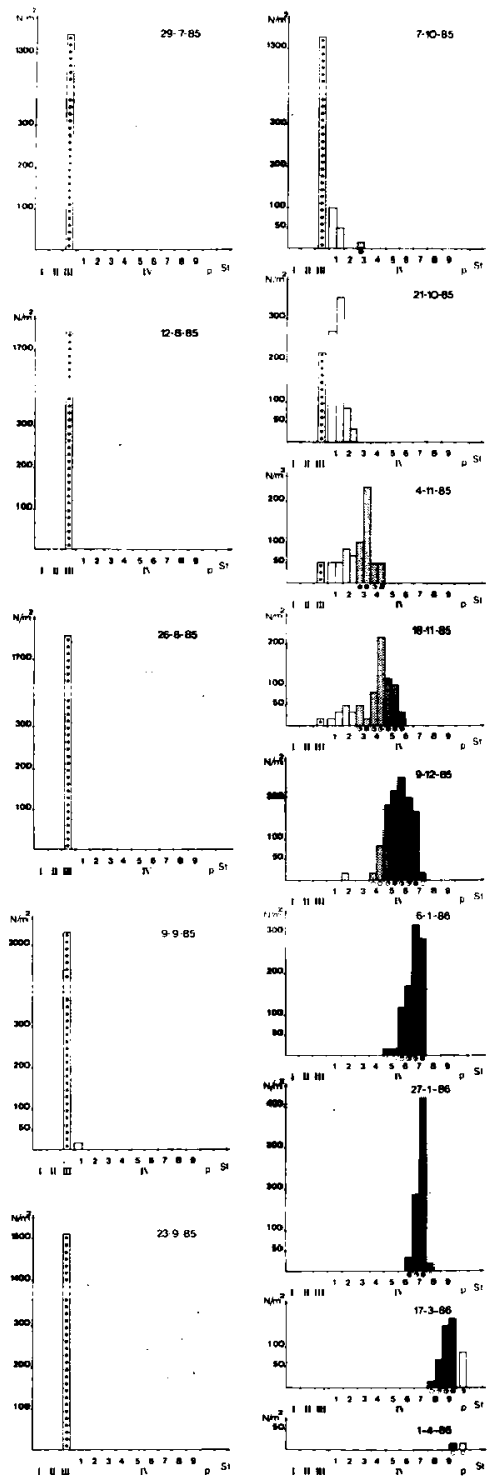
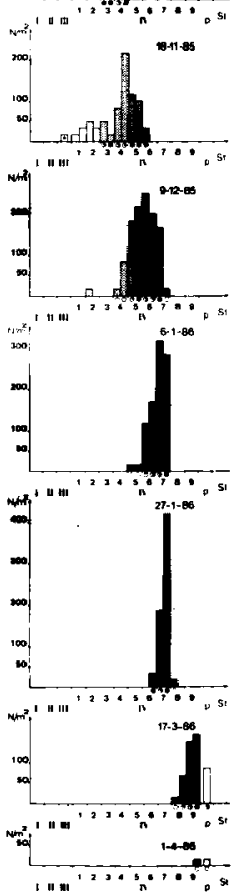
caught on 17th March, 1986, the trap being controlled in the morning (empty) and in the evening ( 2 specimens). The last males were caught between 7 th and 11 th April. It should furthermore be noted that Malaise traps are not very useful for the analysis of emergence of males versus females, as the trap is probably selective for the more active males. Therefore, and because of identification difficulties, the captured females have not been analysed here.

\section{Discussion}

\subsection{Literature}

Tanytarsus sylvaticus is considered as univoltine early spring species. At temperate latitudes in Europe, adults have been captured mainly between mid-March and mid-April (Birkett 1976, Goetghebuer 1921, Langton 1984, Mothes 1966, van der Wulp, 1859). In more nort hern regions or at higher altitudes, where spring starts later, emergences are delayed; the most northern captures were even made in the second half of May (Brundin 1949 sub T. lacteipennis, Reiss 1968, Shilova 1986).

According to Hirvenoja (1963), T. sylvaticus (sub T. aptus) is one of the earliest species in southern Finland. This reference, however, needs to be interpreted with care as it is based on laboratory cultures of samples taken under ice in early April. The fact that imagines emerged four days after sampling only suggests that mature larvae were present.

Only few studies report on emergence data in relation to temperature. In two reservoirs near London, $T$. sylvaticus emerged from late March till midApril. Emergence started at $5.5^{\circ} \mathrm{C}$, with a peak at $6.5^{\circ} \mathrm{C}$ (Mundie 1957). In a reservoir in South Wales, emergence already started in February, but also ended in April ; the mean water temperature in February was $5.5^{\circ} \mathrm{C}$ (Potter \& Learner 1974).

Two references do not corroborate the early spring emergence of $T$. sylvaticus and should therefore be critically re-examined. Goetghebuer (1950) mentioned captures of adults from Belgium in summer : Heusden, 31.8.1942, and Vinderhaute, 16.8.1942. However, the specimens of these localities in the collection Goetghebuer (K.B.I.N., Brussels) are labelled 19.3.1941 and 25.3.1921 respectively.
Learner \& Potter (1974) mentioned a trivoltine $T$. sylvaticus population in South England, emerging in April-early May, in June-July and in August. Not even this first emergence period fits the literature data, and it occurs later than expected at mean water temperatures of $6^{\circ} \mathrm{C}$ in March and of $10^{\circ} \mathrm{C}$ in April. Unfortunately, the material is no longer available for identification control (Learner, pers. com.).

Both cases are discarded in the pressent study.

\subsection{Present results}

Tanytarsus sylvaticus is a strictly univoltine species : the single emergence period in early spring is confirmed both at Mirwart and in the Blankaart reservoir. The year cycle pattern of larval growth and development described above is fairly constant and offers a causal explanation for the scattered observations on adults in literature. A summer arrest in the 3rd instar stage delays growth and development in the 4th stage untill autumn, but a winter development stop, well stressed in substage IV7, prevents pupation until early spring.

\subsubsection{SUMMER DIAPAUSE}

The fact that the development and growth arrest in summer is linked to a distinct development stage and occurs in the same period in both ponds and during the two years of study at Mirwart as well as in the Blankaart reservoir, indicates a summer diapause in the 3rd instar stage in $T$. sylvaticus.

It is possible that a few 2 nd instars are also in diapause. However, the diapause in the 2 nd instar stage does not seem as prominent as in the $3 \mathrm{rd}$ stage : only in pond III at Mirwart 1977, were 2nd instars observed till September.

Photoperiodism is known to govern diapause in chironomids (a.o. Shilova \& Zelentsov 1972, Ineichen et al. 1979). But other factors, such as temperature, may also influence the diapause. It has been mentioned for some chironomid species that low temperatures (Fisher 1974) or high temperatures (Paris \& Jenner 1959) are favourable to diapause in short day (winter) and long day (summer) conditions respectively. The influence of the photoperiod, linked to temperature, on larval development has been particularly demonstrated in Chironomus plumosus and $\mathrm{Ch}$. nuditarsis (Rychen Baganter \& Fischer 1989). 
From the Mirwart and Blankaart data, it appears quite difficult to elucidate the environmental factors which regulate the summer diapause in $T$. sylvaticus. The onset of this diapause coincides with the longest-day condition in a year (second half of June), but also with temperature conditions around $15^{\circ} \mathrm{C}$ or more. At the time of the release of the summer diapause, i.e. in late September - early October, the photoperiod reaches autumn conditions, but temperature drops beneath $15^{\circ} \mathrm{C}$ during the same period. However, after a closer examination of these data, it appears that temperature is not the single diapause regulating factor. It is even doubtful whether temperature has any influence at all. Indeed, in spite of the fact that at Mirwart the autumn temperature-drop in pond III starts already in September, which is a month earlier than in the Blankaart 1985, the release of the summer diapause has exactly the same pattern in both these waters and the same relative proportions of instars are observed in mid-October (50\% 3rd instars - $50 \%$ 4th instars).

Food availability or quality have been excluded as regulating factors for the summer diapause of $T$. sylvaticus. Similar summer diapause patterns are observed in waters of different trophic regimes, with Mirwart pond IV being oligotrophic, pond III rather slightly eutrophic and the Blankaart reservoir eutrophic. Futhermore, during this diapause, other Tanytarsus-species with a supposedly similar detritivorous regime, are highly productive : e.g. two generations of $T$. debilis have developed at Mirwart in the period from June to August (Goddeeris, in prep.).

This extremely constant period withı which the summer diapause occurs, indicates an extremely constant regulating factor as the photoperiodicity. Long days are thought to induce a summer diapause in the 3rd instar stage, while the role of temperature is probably secondary, although high temperatures (i.e. above $15^{\circ} \mathrm{C}$ ) could work to maintain diapause.

\subsubsection{WINTER DIAPAUSE}

The development within the 4th instar stage observed in the Blankaart reservoir indicates a second diapause, this time during the winter.

Both histograms of November 1985 are skewed to the left. This is probably not caused by an asym- metrical release of the 3 rd instar stage, in spite of the important temperature-drop in OstoberNovember (from $18^{\circ} \mathrm{C}$ to $1^{\circ} \mathrm{C}$ ). On the contrary, the moult to the 4th instar stage appears to be symmetrical in time: it lasts two months, from midSeptember till mid-November with the peak in midOctober. A progressive development arrest from substage IV5 onwards, and with an absolute stop at the limit IV7-8a, seems to prevent the substages from being normally distributed in late autumn and in winter. Nearly all larvae have settled in the substages IV 5-IV7 by 12 th December, 1985. The frequency distribution has even become quite narrow and skewed to the left by 27th January, 1986, but the limit IV7b-8a was hardly overstepped and no larvae were prepupating.

The development of the larvae in winter 1984-1985 is only partially known. However, the winter diapause with an absolute development arrest at the limit IV7b-8a is also confirmed by this cohort. On 12th February, 1985, the frequency distribution is rather normal, with a peak in substage IV6b. The distribution has become narrower and skewed to the left by 7 th March, and the development arrest is again stressed at the limit between IV7b-8a.

However, some caution is necessary for the interpretation of small differences in the skewness of the frequency distributions. The subdivision of the $4 \mathrm{th}$ instar stage sensu Wülker \& Götz (1968) may be based on substages of similar duration and a uniform distribution over the substages may be observed in Tanytarsus debilis in conditions which allow continuous development (Goddeeris, in prep.), but small differences in duration between the substages remain possible. A somewhat longer development in one substage results in a weak accumulation of larvae in that substage and could alter the frequency distributions.

The identification difficulties of the various substages (see 2.3. Merhods) are of course more pronounced at the substage limits; these, too, can influence the frequency distributions. Nevertheless, the limit between substage IV7b and IV8a is quite clear, as it is indicated by the onset of the outgrow of the thoracic horn (fig. 4). All substage IV8a instars observed in the Blankaart during the winter (till early March) are at this limit.

Photoperiod and temperature are probably the regulating factors in the winter diapause of $T . s y l$ - 
vaticus. Short daylengths and low temperatures would maintain the diapause, but the role of the temperature appears secondary in full winter, when daylengths are shortest. The settlement of the larvae in substage IV7 was very pronounced in December 1985 - January 1986 and not a single larva began to prepupate. However, the temperature was much higher then than in February - March 1986, when the larvae began to prepupate. Photoperiod is always shorter in December - January than at the emergence of $T$, sylvaticus in March.

Temperature may become more important in the regulation of the diapause in early spring. Over its entire geographical range, $T$. sylvaticus seems to depend on early spring temperatures for emergence rather than on a specific daylength. Temperatures of about $5.5^{\circ} \mathrm{C}$ were mentioned in literature for the onset of emergence and have been confirmed both in the Mirwart ponds and in the Blankaart reservoir. The release of the winter diapause in $T$. sylvaticus is indeed linked to emergence of this species, as is illustrated in the Blankaart in March 1985. On 7th March not a single larva was prepupating (all the IV8a-larvae were at the limit IV7a-8a), but a fortnight later nearly the entire population was prepupating and the emergence had already started. Perhaps a certain threshold temperature must be exceeded to leave the diapause, once the daylength becomes diapause-releasing in February - March : e.g. $3.5{ }^{\circ} \mathrm{C}$ in early March, as indicated by the Blankaart data.

However, the relation between photoperiod and temperature may not be so simple, and various other factors might have to be taken in consideration. In the Blankaart, the differences between the population structures of the diapausing larvae in February 1985 and in January 1986 (the 1986-cohort being more synchronized) remain to be explained.

\subsubsection{EMERGENCE}

The emergence of $T$. sylvaticus is well synchronized and lasts three to four weeks only. Specific threshold temperatures or optimal temperatures for emergence have often been suggested to explain the distinct emergence periods observed in chironomids (Brundin 1949, Sandberg 1969, Laville 1971).

However, a simple threshold temperature for the emergence, not to mention its synchronizing effect, has not been observed in $T$. sylvaticus. The first emergences in the Blankaart are observed at about $5^{\circ} \mathrm{C}(25.3 .1985 ; 17.3 .1986)$ with an optimum at about $7^{\circ} \mathrm{C}$, but the larvae entered the prepupating substages at much lower temperatures several days before, and their further development did not appear blocked by temperature. Furthermore, when the larvae entered the prepupating substages, they had already been synchronized by the winter diapause, strongly pronounced in the substage IV7 and possibly governed by the photoperiodicity of December-January. This synchronized winter cohort of nearly mature larvae is indeed expected to pupate and emerge within a short period in spring.

The release of the winter diapause in $T$. sylvaticus, and the consequent onset of the emergence in March, seem primarily determined by a prepupating threshold temperature of $\pm 3.5^{\circ} \mathrm{C}$ (see 4.2.2.) rat her than by an emergence temperature limit. However, the synchronizing effect of this prepupating temperature threshold on the actual emergence of $T$. sy/vaticus remains unclear. The importance of the photoperiod, i.e. short daylengths as a supposed diapause-maintaining factor in winter, is completely disappearing in February-March, with the lengthening of the days. Potter \& Learner (1974) mentioned $T$. sylvaticus emergence already in February, but this at a mean water temperature of $5.5^{\circ} \mathrm{C}$. As long as the water temperature does not exceed the prepupation threshold temperature in early spring, the emergence of the adults appears delayed and the synchronization of the larval cohort could even be accentuated, this time by this temperature threshold. On the other hand, the emergence may be desynchronized when water temperature fluctuates around the prepupating threshold in spring, with a consequent irregular release of the diapause by the larvae.

The summer diapause is deemed to be of secondary importance for the synchronization of the emergence period, which is restricted to three weeks the next spring : the moulting to the 4 th instar stage at the release of the summer diapause in autumn takes more than two months and appears to be desynchronized.

\subsubsection{GROWTH}

Information about growth in $T$. sylvaticus was obtained through an analysis of the displacement of the mean length of the larvae or the mode in the length frequency distributions in relation to tempe- 
Table 1. T. sylvaticus : mean lengths ( $\bar{x}$ ) or modes $(m)$ in the length frequency distributions at Mirwart used for the calculation of growth in relation to temperature.

\begin{tabular}{|c|c|c|c|c|}
\hline pond ; dates & $\begin{array}{l}\text { length or mode } \\
(\mathrm{mm})\end{array}$ & $\begin{array}{l}\text { interval } \\
\text { (days) }\end{array}$ & $\begin{array}{l}\text { growth rate } \\
(\mathrm{mm} / \text { day })\end{array}$ & $\begin{array}{c}\text { mean temp } \\
\left({ }^{\circ} \mathrm{C}\right)\end{array}$ \\
\hline III ; 19-5/15-6-76 & $1.98(\mathrm{~m}) / 3.11(\bar{x})$ & 27 & 0.42 & 15.26 \\
\hline III $; 22-9 / 18-10-76$ & $3.43(\bar{x}) / 4.28(\bar{x})$ & 26 & 0.033 & 14.7 \\
\hline III ; $10-2 / 15-3-77$ & $6.55(\overline{\mathrm{x}}) / 7.68(\overline{\mathrm{x}})$ & 33 & 0.034 & 6.15 \\
\hline IV $; 25-5 / 7-6-77$ & $1.51(\mathrm{~m}) / 1.87(\overline{\mathrm{x}})$ & 13 & 0.028 & 15.8 \\
\hline III ; 7-6/21- 6-77 & $1.99(\overrightarrow{\mathrm{x}}) / 2.29(\overline{\mathrm{x}})$ & 14 & 0.021 & 14.4 \\
\hline IV ; $7-6 / 21-6-77$ & $1.87(\bar{x}) / 2.35(\bar{x})$ & 14 & 0.034 & 15.35 \\
\hline III ; 13-9/27-9-77 & $3.28(\bar{x}) / 3.56(\bar{x})$ & 14 & 0.020 & 12.9 \\
\hline III $; 27-9 / 11-10-77$ & $3.56(\bar{x}) / 4.14(\bar{x})$ & 14 & 0.041 & 11.5 \\
\hline
\end{tabular}

rature (Goddeeris 1989). However, the results of this method are greatly influenced both by the natality and emergence period and also by the summer and winter diapauses typical of $T$. sylvaticus. Periods of unlimited growth are indeed limited in time. Table 1 presents the data retained at Mirwart for the calculation of length growth in periods ouside the diapause and natality and mortality alterations.

It is obvious that the growth equation $\Delta \mathrm{L} / \Delta \mathrm{t}=$ $0.0316+0.00 \mathrm{~T}$ is only an approximative one : growth at the lowest temperatures is only based on a single measurement. However, important growth at low temperatures in $T$. sylvaticus is confirmed by its life cycle characteristics : an important part of length growth in the 4th instar (and an even more important increase in weight) occurs in late autumn and winter.

\section{Conclusions}

The life cycle of $T$. sylvaticus has a constant annual pattern. Data on adult emergence, both from the literature and from the present study on larval growth and development, indicate that $T$. sylvaticus is a strictly univoltine species, the single emergence period occurring in early spring. This life cycle is mainly determined by two larval diapauses : a summer diapause in the 3rd instar stage (some larvae in the 2nd instar) and a winter diapause as late 4th instars, just before prepupation. The figure 6 illustrates the constant annual pattern in the life cycle of $T$. sylvaticus.
Photoperiodism in relation to temperature is known to govern diapause phenomena in chironomids. However, it has been impossible to elucidate the causal factors of the diapauses in $T$. sylvaticus from our field data. Long daylength (together with temperatures above $15^{\circ} \mathrm{C}$ ?) is supposed to induce summer diapause. The winter diapause of $T$. sylvaticus, on the other hand, is thougth to be mainly governed by the short daylengths of DecemberJanuary. Nevertheless, the release of this diapause (and consequently the onset of emergence) appears to be linked to the crossing of a temperature barrier in early spring i.e. a prepupation threshold temperature of c. $3.5^{\circ} \mathrm{C}$ in $T$. sylvaticus. The summer and winter diapauses of $T$. sylvaticus are both important synchronizing factors and restrict growth and production mainly to late autumn and winter. This species focuses its growth on « bad " seasons, which constitutes an important and specific niche differentiation of T. sylvaticus (cf. Goddeeris 1987). Furthermore, the synchronization caused by the winter diapause induces the really short emergence period in early spring.

\section{Acknowledgements}

We gratefully acknowledge Dr. J. Paulussen and Mr. B. Verhaeghe for their help in sampling the Blankaart reservoir ; Mr. B. Verhaeghe regularly emptied the Malaise trap in 1986. Drs K. Devos provided additional information about the ice-coverage of the reservoir. Many thanks are also due to Dr. K. Martens for valuable comments and to Mrs. V. Arkasi for correcting the manuscript. Mrs. C. Devries-Duchène is thanked for technical assistance with the illustrations. 


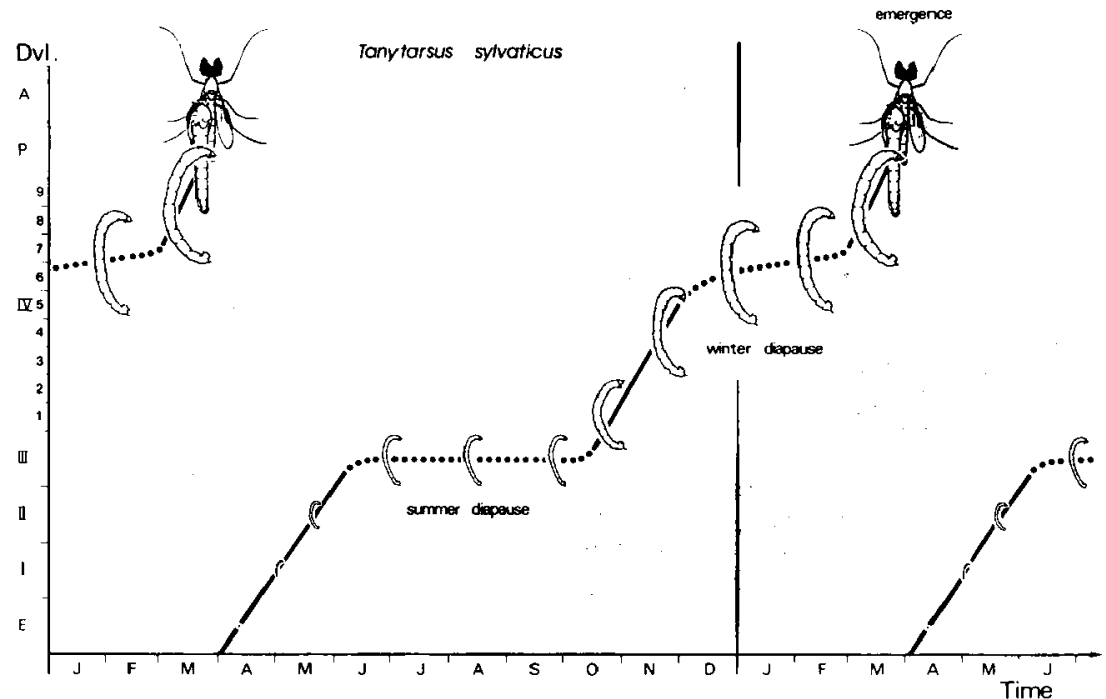

Hig. 6. The annual pattern in the life cycle of Tanytarsus sylvaricus. This life cycle is characterised by a summer diapause in the 3 rd instar stage and a winter diapause as late 4 th instar. The single emergence period occurs in early spring.

\section{References}

Birkett (N.L.). 1976. - Chironomidae (Diptera) trapped in a pennine stream, including two species new to Britain. - Entomologist's Gaz., 27 : 16]-170.

Brundin (L.). 1949. - Chironomiden und andere Bodentiere der sudschwedischen Urgebirgsseen. Ein Beitrag zur Kenntnis der bodenfaunistischen Charakterzüge schwedischer oligotropher Seen. Rep. Inst. Freshwat. Res, Drottningholm, $30: 914 \mathrm{p}$.

Goddeeris (B.R.). 1093. - Het soortspecifieke patroon in de jaarcyclus van de Chironomidae (Diptera) in twee visvijvers te Mirwart (Ardennen), PhD-thesis, Katholieke Univ. Leuven : $177 \mathrm{pp}+$ figures.

Goddeeris (B.R.). 1985. - The larva and pupa of Tanytarsus sylvaticus (Van Der Wulp, 1859) (Chironomidae, Diptera). Bull. Annis Soc. r. belg. Ent., 121 : 311-316.

Cioddeeris (B.R.). 1986. - Diapause in Chironomidae (Diptera) in two ponds in the Belgian Ardennes. Proc. 3rd Eur, Congr. Ent. 1 : 174. Ed. H.H.W. Velthuis, Nederlandse Entomologische Vereniging, Amsterdam.

Goddecris (B.R.). 1987. - The time factor in the niche space of Tanytarsus-species in two ponds in the Belgian Ardennes (Diptera-Chironomidae). Entomologica Scandinavica Supple. ment, $29: 281-288$.

Coddeeris (B.R.) 1989. - A methodology for the study of the life cycle of aquatic Chironomidae (Diptera). Verh. Symp. "Invertebraten van België : 379-385, K.B.I.N., Brussel.
Goetghebuer (M.). 1921. - Chisonomides de Belgique et spécialement de la zone des Flandres. Mém. Mus. r. Hist, nat. Belg. $8: 1.211$.

Goetghebuer (M.). 1950. - Les Chironomides de la région du Bas-Escaut. Bull. Annis. Soc. r. ent. Belg., 86 : 141-163.

Hirvenoja (M.), 1963. - Tanytarsus aptus n.sp. (Diptera, Chironomidae). Suom. hyönt. Aikak., $29: 50-52$.

Ineichen (H.), Riesen-Willi (U.) \& Fischer (J.). 1979. Experimental contributions to the ecology of Chironomus (Diptera). Jl. The influence of the photoperiod on the development of Chironomus plumosus in the 4 th larval instar. Oecologia $39: 161-183$.

Ineichen (H.), Meyer (B.) \& Lezzi (M.). 1983. - Determination of the development stage of living fourth instar larvae of Chironomus tentans. Devl. Biol. 98 : 278-286.

Langton (P.H.). 1984. - A key to pupal exuviae of British Chironomidae. Ed. Langton, March, Cambridgeshire : 324 pp.

Laville (H.). 1971. -- Recherches sur les Chironomides (Diptera) lacustres du massif de Neouvielle (Hautes-Pyrénées). Première Partie : Systématique, écologie, phènologie. Annis Limnol., $7: 173-332$.

Learner (M.A.) \& Potter (D.W.). 1974. - The seasonal periodicity of emergence of insects from two ponds in Hertfordshire, England, with special reference to the Chironomidae (Diptera . Nematocera). Hydrobiologia, 44 ; 495-510. 
Marlier (G.) \& Wattiez (C.). 1977. - Les étangs de Mirwart. In : Duvigneaud (P.) \& Kestemont (P.) (Eds). Productivité biologique en Belgique. Duculot, Paris-Gembloux : 419-452.

Mothes (G.). 1966. - Die makroskopische Bodenfatuna des oligotrophen Stechlinsees im Vergleich zu eutrophen Nachbarseen. Verh. int. Ver. Limmol. $16: 258-262$.

Mundie (J.H.). 1957. - The ecology of Chironomidae in storage reservoirs. Trans. $R$. ent. Soc. Lond. $109:$ 149-232.

Oliver (D.R.). 1971. - Life history of the Chironomidae. A. Rev. Ent. $16: 211-230$.

Paris (O.H.) \& Jenner (C.E.). 1959. - Photoperiodic control of diapause in the pitcher-plant midge Metriocnemus knabi. In Withrov (R.B.) (Ed.), Photoperiodism and related phenomena in plants and animats. A.A.A.S. Washington: $601-624$

Potter (D.W.B.) \& Learner (M.A.). 1974, - A study of the benthic macroinvertebrates of a shallow eutrophic reservoir in South Wales with emphasis on the Chironomidae (Diptera) ; their life-histories and produttion. Arch. Hydrobiol. 74 : 186-226.

Reiss (F.). 1968. - Oekologische und systematische Untersuchungen an Chironomiden (Diptera) des Bodensees. Ein Beitrag zur lakustrischen Chironomidenfauna des nördlichen Alpenvorlandes. Arch. Hydrobiol. 64 : 176-323.

Rychen Bangerter (B.) \& Fischer (J.). 1989. - Different dormancy response in the sympatric Chironomus species $C h$. plumosus and Ch. nuditarsis. Zool. Jb., Syst. Oekol. Geogr. Tiere $116: 145-150$.
Sandberg (G.). 1969. - A quantitative study of chironomid di. tribution and emergence in Lake Erken. Arch. Hydrobio, Suppl. 35 : 119-201.

Shilova (A.I.). 1976. - Chironomids of the Rybinsk reservoi: Izd. Nauka, Leningrad : 1-252.

Shilova (A.I.) \& Zelentsov (N.1.). 1972. - Vliyanie fotoperi. dizma na diapauzu u khironomid ((The influence of phow: periodism on diapause in Chironomidae)). Inf. Byull. Bioi Vnuir, Vod. $13: 37-42$.

Van Damme (M.), Wouters (L.) \& Paulussen (1.). 1987 Funktietoekenning " oppervlaktewater bestend voor de pr" duktie van drinkwater $"$ \& oppervlaktewater bestemd vol: het leven van vissen " in het hydrografisch bekken van ¿ Jjzer. Administrotie Ruimtelijke Ordening en Leefmilict, Brussel : $103 \mathrm{pp}$.

Van der Wulp (F.M.). 1859. - Beschrijving van eenige nieuv of twij felachtige soorten van Diptera uit de familie de Nemw. cera (Description of some new or dubious species of $D_{11}$ tera of the family Nemocera)). Tijdschr. Ent. $2: 159-1 \times$ :

Wülker (W.) \& Götz (P.). 1968. - Die Verwendung der Inıi ginalscheiben aur Bestimmung des Entwicklungszustandes vilt Chironomus-larven (Dipt.), Z. Morph, kol, Tiere, 6? 363-388. 